\title{
ANALISIS FAKTOR YANG BERHUBUNGAN DENGAN PEMBERIAN ASI \\ EKSKLUSIF DI DESA CIKUNIR KECAMATAN SINGAPARNA KABUPATEN TASIKMALAYA TAHUN 2014
}

\author{
OLEH : \\ Hariyani Sulistyoningsih, S.KM,M.KM, \\ Sinta Fitriani, S.KM,MKM, \\ Erwina Sumartini, SST
}

\section{A. ABSTRAK}

Data Susenas tahun 2012 menunjukan pemberian ASI eksklusif di Indonesia masih rendah yaitu 33,6\%. Cakupan ASI eksklusif di Provinsi Jawa Barat pada tahun 2010 mencapai 67,3\% (Susenas, 2010). Menurut Profil Dinas Kesehatan Kabupaten Tasikmalaya, cakupan pemberian ASI eksklusif hanya mencapai 65,93\%, dan Desa Cikunir sebagai desa binaan STIKes Respati termasuk salah satu desa dengan cakupan pemberian ASI eksklusif yang masih rendah.

Penelitian yang dilaksanakan merupakan penelitian kuantitatif dengan metode deksriptif eksploratif. Populasi dalam penelitian ini adalah semua ibu yang memiliki bayi usia 7-12 di Dusun Margamulya Desa Cikunir Kabupaten Tasikmalaya. Seluruh anggota populasi diambil sebagai sampel penelitian. Variabel yang diukur dalam penelitian ini meliputi: pengetahuan, sikap, dukungan suami dan keluarga, serta dukungan petugas kesehatan. Instrumen yang digunakan dalam penelitian ini adalah kuesioner. Pertanyaan yang diberikan berupa pertanyaan terbuka dan tertutup. Kuesioner diwawancarakan kepada responden oleh tim peneliti langsung.

Hasil penelitian di dapatkan bahwa belum semua ibu di Dusun Margamulya Desa Cikunir mengetahui tentang pengertian ASI eksklusif. Masih terdapat ibu yang menyetujui pemberian makanan pendamping sebelum bayi berusia 6 bulan, serta menyetujui penghentian pemberian ASI ketika bayi sakit. Semua ibu di Dusun Margamulya Desa Cikunir mendapatkan dukungan suami dan keluarga dalam pemberian ASI Eksklusif. serta terdapat satu orang ibu yang mengatakan tidak mendapatkan informasi dan anjuran memberikan ASI eksklusif ketika memeriksakan diri kepada tenaga kesehatan.

Puskesmas hendaknya mengoptimalkan program yang sudah ada dengan melibatkan semua pemegang program di Puskesmas untuk mengupayakan promosi ASI eksklusif sehingga penyampaian informasi tidak hanya dilakukan oleh bidan.

Kata Kunci : ASI Eksklusif, sikap, dukungan suami, serta peran petugas 


\section{B. PENDAHULUAN}

Pemberian ASI merupakan upaya pemenuhan kebutuhan gizi diawal kehidupan manusia. ASI merupakan makanan yang paling baik dan paling sempurna untuk bayi karena kandungan gizinya yang paling tinggi dibandingkan dengan makanan bayi yang dibuat oleh manusia ataupun susu hewan seperti susu sapi. Adanya zat kebal di dalamnya tidak dapat tergantikan oleh susu formula yang paling hebat dan mahal sekalipun. Air susu ibu mengandung lebih dari 200 unsur pokok antara lain zat putih telur, lemak, karbohidrat, vitamin, mineral, faktor pertumbuhan, hormon, enzim, zat kekebalan dan sel darah putih (Khasanah, 2010).

ASI merupakan bahan makanan yang sesuai dengan bayi, zat-zat gizi yang terkandung dalam ASI telah sesuai dengan keadaan dan kebutuhan bayi. Selain nutrient ASI lengkap ASI juga mengandung faktor pelindung yaitu antibody, sel darah putih, enzim dan hormon tertentu, tidak menimbulkan alergi sedangkan susu formula akan merangsang aktivitas system imun yang sering menyebabkan alergi, mengoptimalkan pertumbuhan, menurunkan resiko gigi berlubang, efek psikologis positif. Manfaat lain dari ASI yaitu menjaga stamina ibu, mengatur kehamilan, pemberian ASI pada bayi memiliki aspek eknomis yang menguntungkan dann ASI itu praktis. Bayi usia 0-6 bulan membutuhkan zat gizi spesifik yang sepenuhnya dapat dipenuhi dari ASI. Pemberian ASI saja kepada bayi tanpa diberi makanan dan minuman lain sejak lahir sampai 6 bulan dikenal dengan istilah dengan ASI Eksklusif (Depkes, 2003).

ASI mengandung antibodi dalam jumlah besar yang berasal dari tubuh seorang ibu. Antibodi tersebut membantu bayi menjadi tahan terhadap penyakit, selain itu juga meningkatkan sistem kekebalan tubuh bayi. Telah terbukti bahwa bayi yang diberi ASI lebih kuat dan terhindar dari beragam penyakit seperti asma, pneumonia, diare, infeksi telinga, alergi kanker anak, multiple scleroses, penyakit Crohn, diabetes, radang usus buntu, dan obesitas. Bayi yang diberi ASI rata-rata memiliki IQ 6 poin lebih tinggi dibandingkan dengan bayi yang diberi susu formula. Angka kejadian diare yang disebabkan karena tidak dapat mencerna laktosa jarang ditemukan pada bayi yang mendapat ASI, karena penyerapan laktosa ASI lebih baik (Badriul Hegar DKK). Apabila bayi diberikan MP-ASI saat usia di bawah 6 bulan, sistem pencernaannya belum memiliki enzim untuk mencerna makanan sehingga memberatkan kerja pencernaan dan ginjal bayi. Selain itu usus bayi belum dapat menyaring protein dalam jumlah besar, sehingga dapat menimbulkan reaksi batuk, diare, kolik dan alergi (Nurhaeni Arif, 2009).

Data Susenas tahun 2012 menunjukan pemberian ASI eksklusif di Indonesia masih rendah yaitu 33,6\%. Cakupan ASI eksklusif di Provinsi Jawa Barat pada tahun 2010 mencapai 67,3\% (Susenas, 2010). Menurut Profil Dinas Kesehatan Kabupaten Tasikmalaya, cakupan pemberian ASI eksklusif hanya mencapai 65,93\%, dan Desa Cikunir sebagai desa binaan STIKes Respati termasuk salah satu desa dengan cakupan pemberian ASI eksklusif yang masih rendah. Berdasarkan latarbelakang yang telah dipaparkan, peneliti bermaksud melakukan kajian tentang faktor yang berhubungan dengan pemberian ASI eksklusif di Dusun Margamulya Desa Cikunir Kecamatan Singaparna.

Tujuan penelitian adalah Mengetahui faktor faktor apa saja yang 
mempengaruhi kegagalan pemberian ASI Eksklusif pada bayi di pemberian ASI eksklusif di Dusun Margamulya Desa Cikunir Kecamatan Singaparna Tahun 2015.

\section{METODOLOGI PENELITI}

1. Jenis penelitian

Penelitian yang dilaksanakan merupakan penelitian kuantitatif dengan metode deksriptif eksploratif, yaitu penelitian yang bertujuan untuk mendeskripsikan dan menggali faktor yang mempengaruhi pemberian ASI eksklusif di Dusun Margamulya Desa Cikunir Kabupaten Tasikmalaya.

2. Populasi dan sampel

Populasi dalam penelitian ini adalah semua ibu yang memiliki bayi usia 712 di Dusun Margamulya Desa Cikunir Kabupaten Tasikmalaya. Seluruh anggota populasi diambil sebagai sampel penelitian

3. Variabel

Variabel yang diukur dalam penelitian ini meliputi: pengetahuan, sikap, dukungan suami dan keluarga, serta dukungan petugas kesehatan.

4. Instrumen penelitian

Instrumen yang digunakan dalam penelitian ini adalah kuesioner. Pertanyaan yang diberikan berupa pertanyaan terbuka dan tertutup. Kuesioner diwawancarakan kepada responden oleh tim peneliti langsung.

5. Pengolahan data

Pengolahan data penelitian dilakukan dengan cara :

\section{a. Editing}

Tahapan ini dilakukan dengan cara mengecek kelengkapan kebutuhan data penelitian.

b. Coding .

c. Entry data

Proses memasukan data ke program komputerisasi untuk disajikan dalam bentuk tabel dan dianalisis secara narasi
6. Analisis data

Analisis data dalam penelitian ini adalah analisis univariat dan bivariat. Analisis ini menghasilkan distribusi frekuensi untuk menggambarkan tiap-tiap variabel yang akan diteliti.

\section{HASIL PENELITIAN}

1. Karakteristik Responden

Responden dari penelitian ini adalah ibu dari balita usia 7-12 bulan yang berada di Dusun Margamulya yaitu sebanyak 6 orang. Jika dilihat dari tingkat pendidikan, sebanyak 3 orang (50\%) berpendidikan SMP, 2 orang $(33,3 \%)$ berpendidikan SD, dan 1 orang $(16,7 \%)$ Sarjana, dan semua responden memiliki pekerjaan sebagai ibu rumah tangga. Usia rata-rata ibu adalah 25,5 tahun dengan usia termuda 20 tahun dan usia ibu yang paling tua adalah 40 tahun.

\section{Karakteristik Bayi}

Bayi yang dijadikan sampel sebanyak 6 orang yang terdiri dari 3 orang laki-laki dan 3 orang perempuan dan berusia antara 7 sampai 12 bulan dengan rata-rata usia 8,83 bulan. Bayibayi yang dijadikan sampel terlahir dengan berat badan antara 2800-3700 gram dan rata-rata 3133,33 gram.

3. Gambaran Pemberian ASI Eksklusif di Dusun Margamulya Desa Cikunir Kecamatan Singaparna Tahun 2015

Tabel 7.1 Gambaran Pemberian ASI Eksklusif di Dusun Margamulya Desa Cikunir Kecamatan Singaparna Tahun 2015

\begin{tabular}{|l|c|c|}
\hline \multicolumn{1}{|c|}{ Pemberian ASI } & n & \% \\
\hline Eksklusif & 4 & 66,7 \\
\hline Tidak Eksklusif & 2 & 33,3 \\
\hline Jumlah & 6 & 100,0 \\
\hline
\end{tabular}


data yang dikumpulkan menunjukkan bahwa sebanyak $66,75 \%$ bayi mendapatkan ASI secara eksklusif dengan demikian masih terdapat bayi yang tidak mendapatkan ASI secara eksklusif.

\section{Gambaran Pengetahuan Ibu Tentang ASI Eksklusif di Dusun Margamulya Desa Cikunir Kecamatan Singaparna Tahun 2015.}

Tabel 7.2 Gambaran Pengetahuan Ibu Tentang ASI Eksklusif di Dusun Margamulya Desa Cikunir Kecamatan Singaparna Tahun 2015

\begin{tabular}{|l|l|lr|}
\hline No & \multicolumn{1}{|c|}{$\begin{array}{l}\text { Item } \\
\text { Pengetahuan }\end{array}$} & \multicolumn{1}{|c|}{$\begin{array}{c}\text { Hasil pengumpulan } \\
\text { data }\end{array}$} \\
\hline 1 & $\begin{array}{l}\text { Pengertian ASI } \\
\text { eksklusif }\end{array}$ & $\begin{array}{l}\text { Terdapat orang } \\
\text { responden yang tidak } \\
\text { dapat partama } \\
\text { pengertian ASI eksklusif } \\
\text { secara tepat }\end{array}$ \\
\hline 2 & $\begin{array}{l}\text { Usia pertama } \\
\text { pemberian } \\
\text { makanan selain } \\
\text { ASI }\end{array}$ & $\begin{array}{l}\text { Seluruh responden } \\
\text { mengetahui usia pertama } \\
\text { bayi boleh mendapatkan } \\
\text { makanan pendamping (6 } \\
\text { bulan) }\end{array}$ \\
\hline 3 & $\begin{array}{l}\text { Pemberian } \\
\text { susu formula } \\
\text { sebagai } \\
\text { pengganti ASI }\end{array}$ & $\begin{array}{l}\text { Terdapat 2 } \\
\text { responden } \\
\text { mengatakan susu formula } \\
\text { dapat menggantikan ASI }\end{array}$ \\
\hline 4 & $\begin{array}{l}\text { Kelebihan ASI } \\
\text { dibandingkan } \\
\text { susu formula }\end{array}$ & $\begin{array}{l}\text { Seluruh respon dapat } \\
\text { menyebutkan 1 kelebihan } \\
\text { ASI dibandingkan susu } \\
\text { formula }\end{array}$ \\
\hline 5 & $\begin{array}{l}\text { Penghentian } \\
\text { pemberian ASI } \\
\text { jika bayi sakit }\end{array}$ & $\begin{array}{l}\text { Terdapat 1 orang ibu } \\
\text { mengatakan bahwa ASI } \\
\text { harus dihentikan ketika } \\
\text { bayi sakit agar bayi tidak } \\
\text { rewel }\end{array}$ \\
\hline
\end{tabular}

5. Gambaran Sikap Ibu Tentang ASI Eksklusif di Dusun Margamulya Desa Cikunir Kecamatan Singaparna Tahun 2015.

\section{Tabel 7.3 Gambaran Sikap Ibu Tentang ASI Eksklusif di Dusun Margamulya Desa Cikunir Kecamatan Singaparna Tahun 2015}

\begin{tabular}{|c|c|c|}
\hline No & Pernyataan & $\begin{array}{c}\text { Hasil } \\
\text { Pengumpulan } \\
\text { Data }\end{array}$ \\
\hline 1 & $\begin{array}{l}\text { Saat yang tepat untuk } \\
\text { memberikan } \\
\text { makanan/minuman lain } \\
\text { selain ASI kepada bayi } \\
\text { adalah ketika bayi } \\
\text { berusia } 3 \text { bulan }\end{array}$ & $\begin{array}{l}\text { Terdapat } 1 \\
\text { orang } \\
\text { responden } \\
\text { mengatakan } \\
\text { setuju dengan } \\
\text { pernyataan ini }\end{array}$ \\
\hline 2 & $\begin{array}{l}\text { Pemberian susu formula } \\
\text { boleh dilakukan sebagai } \\
\text { pengganti ASI karena } \\
\text { kualitas susu formula } \\
\text { sama dengan kualitas } \\
\text { ASI }\end{array}$ & $\begin{array}{l}\text { Terdapat } 1 \\
\text { orang responden } \\
\text { yang } \\
\text { mengatakan } \\
\text { setuju dengan } \\
\text { pernyataan ini }\end{array}$ \\
\hline 3 & $\begin{array}{lrr}\text { Pemberian } & \text { ASI } & \text { harus } \\
\text { dihentikan ketika } & \text { bayi } \\
\text { mengalami } & \text { diare } \\
\text { ataupun sakit } & \text { yang } \\
\text { lainnya } & & \end{array}$ & $\begin{array}{l}\text { Seluruh } \\
\text { responden } \\
\text { mengatakan } \\
\text { tidak setuju } \\
\text { dengan } \\
\text { pernyataan ini }\end{array}$ \\
\hline 4 & $\begin{array}{l}\text { Kebutuhan gizi bayi } \\
\text { usia } 0-6 \text { bulan dapat } \\
\text { terpenuhi dengan } \\
\text { memberikan ASI }\end{array}$ & $\begin{array}{l}\text { Terdapat } 1 \\
\text { orang responden } \\
\text { yang } \\
\text { mengatakan } \\
\text { tidak setuju } \\
\text { dengan } \\
\text { pernyataan ini }\end{array}$ \\
\hline 5 & $\begin{array}{l}\text { Pemberian ASI jangan } \\
\text { dihentikan ketika bayi } \\
\text { sedang sakit }\end{array}$ & $\begin{array}{l}\text { Terdapat } 1 \\
\text { orang responden } \\
\text { yang } \\
\text { mengatakan } \\
\text { setuju dengan } \\
\text { pernyataan ini }\end{array}$ \\
\hline
\end{tabular}


Jika melihat hasil pengumpulan data maka kepada bayinya. Sebuah perilaku yang didasari dapat diketahui bahwa masih terdapat sikap oleh pengetahuan, kesadaran, dan sikap positif responden yang belum mendukung pemberian akan membentuk sebuah perilaku yang langgeng, ASI secara eksklusif, diantaranya yaitu masih ada sebaliknya sebuah perilaku yang tidak didasari oleh yang setuju bahwa susu formula dapat pengetahuan dan kesadaran akan membuat menggantikan ASI, pemberian ASI harus perilaku tersebut tidak akan bertahan lama. dihentikan ketika bayi sakit, serta tidak setuju jika Kurangnya pengetahuan ataupun kurangnya kebutuhan gizi bayi usia 0-6 bulan dapat kemampuan ibu dalam menerapkan informasi tercukupi dengan ASI.

6. Gambaran Dukungan suami dan Keluarga Ketidaktahuan masyarakat tentang pemberian ASI dalam Pemberian ASI Eksklusif di Dusun eksklusif selama 6 bulan menyebabkan banyak Margamulya Desa Cikunir Kecamatan orang tua memberikan makanan pendamping Singaparna Tahun 2015.

Hasil pengumpulan data menunjukkan sebelum bayi berusia 6 bulan (Notoatmodjo, 2003).

bahwa seluruh suami menyarankan istrinya

Selain pengetahuan, sikap juga memberikan ASI secara eksklusif dan tidak ada yang melarang pemberian ASI. Sebanyak 4 orang responden mengatakan ada anggota keluarga lain (mertua, saudara) yang menyarankan menghentikan pemberian ASI eksklusif dengan alasan kasihan kepada bayi atau khawatir bayi tidak kenyang.

Jika dilihat dari dukungan suami, responden mengatakan bahwa bentuk dukungan suami berupa memberikan makanan yang bergizi, mneyiapkan buah-buahan, dan menyarankan terus memberikan ASI. Sebanyak 3 orang ibu mendapatkan dukungan dari suami berupa bantuan dalam menyelesaikan pekerjaan rumah tangga ketika bayi mennagis karena ingin menyusu.

7. Gambaran Dukungan Tenaga Kesehatan dalam Pemberian ASI Eksklusif di Dusun Margamulya Desa Cikunir Kecamatan Singaparna Tahun 2015.

Berdasarkan hasil pengumpulan data menunjukkan bahwa sebanyak 5 orang responden mengatakan bahwa mereka mendapat dukungan untuk memberikan ASI secara eksklusif dari tenaga kesehatan. Bentuk dukungan yang diterima berupa pemberian informasi tentang ASI eksklusif serta anjuran/dorongan kepada ibu untuk memberikan ASI eksklusif.

\section{E. PEMBAHASAN}

Pengetahuan merupakan hal yang sangat penting dalam membentuk tindakan sesorang, termasuk perilaku ibu dalam memberikan ASI memberikan pengaruh terhadap tindakan seseorang. Sikap menggambarkan suka atau tidak suka seseorang terhadap suatu obyek, dalam hal ini terhadap pemberian ASI kepada bayi. Meskipun sikap positif ibu terhadap pemberian ASI tidak selamanya akan terwujud dalam tindakan nyata ibu dalam memberikan ASI, namun sikap ibu terhadap pemberian ASI dapat menyebabkan ibu mendekati atau menjauhi hal-hal yang berhubungan dengan pemberian ASI.

Dukungan suami sebagai orang yang terdekat dengan istri diperlukan untuk memotivasi sang istri untuk memberikan ASI secara ekslusif. Dukungan yang diberikan dapat berupa adanya upaya suami untuk meberikan informasi tentang Asi eksklusif, mengingatkan istri untuk memberikan ASI eksklusif, suami memberikan kesempatan pada istri untuk menyusui di setiap saat bayi membutuhkan, atau suami bersedia membantu menyelesaikan pekerjaan rumah tangga yang biasa dikerjakan oleh istrinya ketika sang isrti harus menyusui bayinya. Hal lain yang dapat dilakukan suami adalah berupaya menyediakan makanan yang bergizi bagi istrinya sehingga istri dapat memproduksi ASI dengan kualitas dan kuantitas yang baik.

Hal lain yang dapat menunjang keberhasilan menyusui adalah adanya dukungan dari tenaga kesehatan dalam hal ini setelah masa persalinan. Kontak dengan tenaga kesehatan pada masa nifas juga perlu dilakukan sebagai salah satu standar dalam 
pelayanan kebidanan. Hal yang dilakukan dalam kontak pertama diantaranya adalah melakukan pemeriksaan kesehatan ibu dan bayi, membantu ibu dalam menyusui, memotivasi ibu untuk memberikan ASI secara eksklusif, serta penyuluhan dan pelayanan KB. Pemantauan pemberian ASI dalam 3 hari pertama diharapkan dapat membantu keberlanjutan pemberian ASI sehingga pemberian ASI eksklusif sampai 6 bulan dapat dilakukan (Depkes, 2000). Penyampaian informasi dengan metode konseling ataupun wawancara membutuhkan waktu yang cukup karena pendekatan dilakukan personal/satu per satu. Keterbatasan waktu dan banyaknya tugas yang harus dilakukan oleh seorang bidan menyebabkan penyampaian informasi tentang ASI cukup sulit dilakukan dengan pendekatan individual. Hal ini dapat diantisipasi dengan memilih metode lain yaitu metode pendidikan kelompok, baik dengan kelompok besar ataupun kelompok kecil. Salah satu hal yang dapat dicoba dilakukan dalam upaya penyampaian informasi dalam bentuk kelompok adalah dengan membentuk kelas ibu, bagi ibu hamil ataupun nifas.

Penyampaian informasi melalui kelas ibu dapat lebih efektif karena dengan waktu yang lebih singkat dapat menyampaikan informasi dengan jumlah sasaran lebih banyak. Beberapa metode yang dapat digunakan dalam mengelola kelas ibu sebagai upaya pendidikan kelompok adalah diskusi kelompok, curah pendapat, buzz group, dan bermain peran (Notoatmodjo, 2003).

Salah satu hal yang turut mendukung keberhasilan proses penyampaian informasi mengenai segala sesuatu yang berhubungan dengan menyusui adalah adanya alat bantu atau media yang tepat. Media atau alat bantu sebaiknya selain sebagai sumber informasi bagi ibu juga dapat berfungsi sebagai alat pemantau status kesehatan ibu dan bayi. Instrumen yang sudah ada namun mungkin penggunaannya belum maksimal adalah Buku Kesehatan Ibu dan Anak (KIA). Buku ini memuat berbagai informasi tentang kesehatan ibu (hamil, bersalin, dan nifas) dan anak (bayi baru lahir, bayi, dan balita) serta berbagai informasi tentang cara memelihara dan merawat kesehatan ibu dan anak (Depkes, 2006). Setiap ibu hendaknya memiliki buku KIA dan ibu serta anggota keluarganya mendapatkan penjelasan tentang penggunaan buku tersebut. Hasil penelitian Kusumayati (2008) menunjukkan bahwa penggunaan buku KIA berpotensi untuk mendorong ibu memiliki perilaku yang positif, seperti mengkonsumsi makanan bergizi, mengkonsumsi tablet besi selama kehamilan, menyusui dini, serta memberikan ASI eksklusif. Selain itu, penggunaan buku KIA mendorong ibu untuk melakukan perawatan antenatal, imunisasi Tetanus Toxoid (TT) serta melakukan persalinan di tenaga kesehatan.

\section{F. SIMPULAN DAN SARAN}

1. Simpulan

a. Belum semua ibu di Dusun Margamulya Desa Cikunir mengetahui tentang pengertian ASI eksklusif, ASI tetap harus diberikan meskipun ibu/bayi sakit, serta bahwa kualitas susu formula tidak bisa disetarakan dengan ASI

b. Masih terdapat ibu yang menyetujui pemberian makanan pendamping sebelum bayi berusia 6 bulan, serta menyetujui penghentian pemberian ASI ketika bayi sakit.

c. Semua ibu di Dusun Margamulya Desa Cikunir mendapatkan dukungan suami dan keluarga dalam pemberian ASI Eksklusif.

d. Terdapat satu orang ibu yang mengatakan tidak mendapatkan informasi dan anjuran memberikan ASI eksklusif ketika memeriksakan diri kepada tenaga kesehatan.

2. Saran

a. Bagi tenaga kesehatan di Desa CIkunir

Seluruh bidan yang berada di wilayah kerja Desa Cikunir 
hendaknya memberikan pelayanan antenatal yang berkualitas dan menyeluruh, tidak hanya memperhatikan status kesehatan ibu tapi juga memberikan informasi tentang ASI eksklusif. Promosi tentang ASI pada masa kehamilan sangat diperlukan agar ibu hamil memiliki pengetahuan yang cukup tentang ASI, memiliki perencanaan yang baik dalam proses menyusui yang akhirnya akan memberikan kesiapan mental kepada ibu untuk menyusui eksklusif.

b. Bagi Puskesmas Singaparna

Puskesmas hendaknya mengoptimalkan program yang sudah ada dengan melibatkan semua pemegang program di Puskesmas untuk mengupayakan promosi ASI eksklusif sehingga penyampaian informasi tidak hanya dilakukan oleh bidan.

c. Bagi para suami

Suami harus memberikan dukungan penuh kepada istri agar dapat menyusui dengan baik. Hal yang dilakukan suami diantaranya adalah: memberikan makanan yang bergizi, memberikan kesempatan kepada istri untuk meyusui, mengantar istri memeriksakan diri kepada petugas kesehatan, serta membantu meringankan pekerjaan runah tangga yang seharusnya dikerjakan istri

\section{G. DAFTAR PUSTAKA}

Damayanti, D. 2010. Makanan Pendamping ASI. Jakarta: Gramedia Pustaka Utama.

Departemen Kesehatan RI. 1994, Pedoman Pelayanan Antenatal di Tingkat Pelayanan Dasar. Departemen Kesehatan, Jakarta. . 2006, Buku

Kesehatan Ibu dan Anak, Departemen Kesehatan, Jakarta.

Kusumayati, Agustin. 2008, The Effects of Maternal and Child Health Handbook Utilization in West Sumatra, Indonesia, [Disertasi], Graduate School of Human Sciences, Osaka.

Notoatmodjo, S. 2010. Pendidikan Kesehatan dan Ilmu Perilaku. Jakarta: PT. Rineka Cipta

Ramaiah, Savitri. 2006. ASI dan Menyusui Panduan Praktis bagi Ibu Setelah Melahirkan. Jakarta: PT. Bhuana Ilmu Populer.

Roesli, Utami. 2004. Mengenal ASI Eksklusif. Jakarta: Trubus Agriwidya.

Soetjiningsih, editor. 1997. ASI Petunjuk untuk Tenaga Kesehatan. Jakarta: Penerbit Buku Kedokteran EGC. 